\title{
The academic productivity and impact of the University of Toronto Neurosurgery Program as assessed by manuscripts published and their number of citations
}

\author{
Christopher S. Lozano, ${ }^{1}$ Joseph Tam, PhD, ${ }^{1}$ Abhaya V. Kulkarni, MD, PhD, ${ }^{1,2}$ and \\ Andres M. Lozano, MD, PhD1,3 \\ 1Division of Neurosurgery, Department of Surgery, University of Toronto; ${ }^{2}$ Division of Neurosurgery, Hospital for Sick Children; \\ and ${ }^{3}$ Division of Neurosurgery, Toronto Western Hospital, Toronto, Ontario, Canada
}

\begin{abstract}
OBJECT Recent works have assessed academic output across neurosurgical programs using various analyses of accumulated citations as a proxy for academic activity and productivity. These assessments have emphasized North American neurosurgical training centers and have largely excluded centers outside the United States. Because of the long tradition and level of academic activity in neurosurgery at the University of Toronto, the authors sought to compare that program's publication and citation metrics with those of established programs in the US as documented in the literature. So as to not rely on historical achievements that may be of less relevance, they focused on recent works, that is, those published in the most recent complete 5-year period.

METHODS The authors sought to make their data comparable to existing published data from other programs. To this end, they compiled a list of published papers by neurosurgical faculty at the University of Toronto for the period from 2009 through 2013 using the Scopus database. Individual author names were disambiguated; the total numbers of papers and citations were compiled on a yearly basis. They computed a number of indices, including the ih(5)-index (i.e., the number of citations the papers received over a 5 -year period), the summed $h$-index of the current faculty over time, and a number of secondary measures, including the $i g(5)$, ie(5), and i10(5)-indices. They also determined the impact of individual authors in driving the results using Gini coefficients. To address the issue of author ambiguity, which can be problematic in multicenter bibliometric analyses, they have provided a source dataset used to determine the ih(5) index for the Toronto program.

RESULTS The University of Toronto Neurosurgery Program had approximately 29 full-time surgically active faculty per year (not including nonneurosurgical faculty) in the 5-year period from 2009 to 2013. These faculty published a total of 1217 papers in these 5 years. The total number of citations from these papers was 13,434. The ih(5)-index at the University of Toronto was 50 .
\end{abstract}

CONCLUSIONS On the basis of comparison with published bibliometric data of US programs, the University of Toronto ranks first in terms of number of publications, number of citations, and ih(5)-index among neurosurgical programs in North America and most likely in the world.

http://thejns.org/doi/abs/10.3171/2014.12.JNS142553

KEY WORDS $h$-index; ih(5)-index; e-index; $g$-index; i10-index; academic neurosurgery; bibliometrics

$\mathrm{N}$ EUROSURGICAL programs can be characterized and ranked using a number of parameters, including clinical volume, patient outcomes, teaching achievements, and the leadership positions held by their faculty in learned and prestigious societies, panels, agencies, and editorial boards as well as their research accomplishments and publications. These attributes, and particu- larly, the relative weight that one assigns to each individual component, are prone to subjective factors which make it challenging when one attempts to assess how the programs stack up relative to each other.

Given these important caveats, the appraisal of academic productivity in neurosurgery is multifaceted and accurate assessment can be difficult. One objective method, 
however, is an assessment of the number of papers published by a program and their relative influence in the field, with the number of times a work has been cited by others serving as a surrogate for impact. ${ }^{13}$ To this end, groups have now compiled bibliometric indices across neurosurgical training programs as a proxy measure of academic productivity. ${ }^{16,19,20,22,42,52,54,55,59}$ These compilations have emphasized North American programs and particularly programs based in the United States. The accurate compilation of such data is complex and subject to inaccuracy. The work of faculty with common names, for example, can be misattributed, and faculty can be overlooked in search strings or double-counted. It is sometimes difficult to ascertain who within a neurosurgical program is an active neurosurgeon versus, for example, an honorary or a retired member of the faculty, or to distinguish those who are listed as neurosurgical faculty but are not neurosurgeons as occurs when neurologists or PhD scientists hold appointments in neurosurgery departments.

To obtain measures and directly compare the ranking of the University of Toronto Neurosurgery Program's academic productivity, we compiled citation data using manuscripts that could be unambiguously attributed to our faculty. To directly compare our results to those in the literature, we harmonized the time window and methodology used in the analysis to match that available for other programs as recently documented..$^{19,20,50}$ Such an assessment gives an appraisal of the productivity of the University of Toronto Neurosurgery Program in relation to other programs and may be the basis on which to formulate future recommendations and adjustments to neurosurgical programs to enhance or optimize academic productivity. So as to not rely on historical achievements that may be of less relevance today, we focused on recent works, that is, papers published in the last 5 years, as was done for the assessment of all North American neurosurgical programs documented. ${ }^{19,20,50}$

\section{Methods}

The surgically active neurosurgery faculty at the University of Toronto (defined as individuals who are board certified in neurosurgery, have "on call" responsibilities, and perform surgery with greater than $25 \%$ of activity dedicated to clinical effort) were identified and verified for the 5-year period from 2009 through 2013. The number of active years in this 5-year period for each of these individual "authors" was compiled. The years of active contribution for those who left the program for reasons of retirement, relocation, or death were determined. Similarly, for new hires, only the years of active participation within this 5 -year period were counted. Manuscripts published and citations obtained prior to being appointed or after leaving the Toronto program were not included. So as not to confound the issue of academic productivity by discipline, we did not include publications by nonneurosurgeons who may be appointed to the neurosurgery faculty when these publications did not include at least 1 active faculty-appointed neurosurgeon.

We then performed a Scopus author search (www.scopus.com) using the author names and imposing the search limit of "University of Toronto" as an affiliation parameter. From this generated list of authors, we selected those who were confirmed to be active Toronto neurosurgical faculty. Faculty names were manually verified, and their authorship was unambiguously validated (for example, by correcting for multiple individuals having the same surname and initials and by correcting errors, omissions, and duplications by cross-referencing to papers that appeared listed in their individual curricula vitae). The total number of papers published by these authors in the 2009-2013 time windows was compiled. Duplicates were identified and papers authored by more than 1 faculty member were counted once with attribution to a single author based on the rank order of appearance in authorship (first, then second, then last, then third, and so on). A citation report was then created based on these publications using the Scopus database. Only papers published between 2009 and 2013 were considered, and only the citations to these papers in this 5-year window were counted. The papers were then sorted by citation number and ih(5)-index; namely, the number of papers published in this 5-year interval that were cited $h$ or more times was determined. Secondary indices were similarly calculated, including the ig(5)-index, $i e(5)$-index, and $i 10(5)$-index. We also calculated the Gini coefficient for publications and citations as a measure of equality of contribution of individual faculty to these metrics. All calculations were carried out during the month of July 2014. The definition and significance of these various measures are shown in Table 1.

\section{Results}

The number of active neurosurgeons on faculty at the University of Toronto in the 2009-2013 period ranged from 28 to 31 per year, with a mean number of 29.2 (Table 2 ). The total number of publications by these neurosurgeons in this time period was 1217, increasing from 185 to 289 per year over the 5 years. The mean number of publications per neurosurgeon also increased-from 6.6 to 9.3 per year, a $41 \%$ increase - with a mean of 8.3 publications per author per year over the 5-year period. The total number of citations for papers published in this 5-year window was 13,434 , or 89.68 per surgeon per year.

These 1217 papers were sorted by their total number of citations to generate the $i h(5)$-index. The $i h(5)$-index for the faculty was $50-$ i.e., in this 5 -year period there were 50 papers published which were cited 50 or more times within the same 5 years. These works are shown in Tables $3^{1-6,8-12,14,15,17,18,21,23-41,43-49,51,52,56-58,60-62}$ and 4. Review, consensus, and guideline works featured prominently among the most highly cited papers, as did original works in the field of tumor biology and functional neurosurgery.

Twelve faculty members (approximately 40\%) published papers that contributed to the $i h(5)$-index. The contributions were not equal, however, and generally followed the Pareto principle (also known as the 80-20 rule) where approximately $80 \%$ of papers in the $i h(5)$-index came from $20 \%$ of the faculty. Another measure of the principle of relative contribution or factor sparsity, the Gini coefficient, was calculated to be 0.61 for publications and 0.72 for citations where 0 indicates total equality and 1 indicating total 
TABLE 1. Definition of bibliometric indices

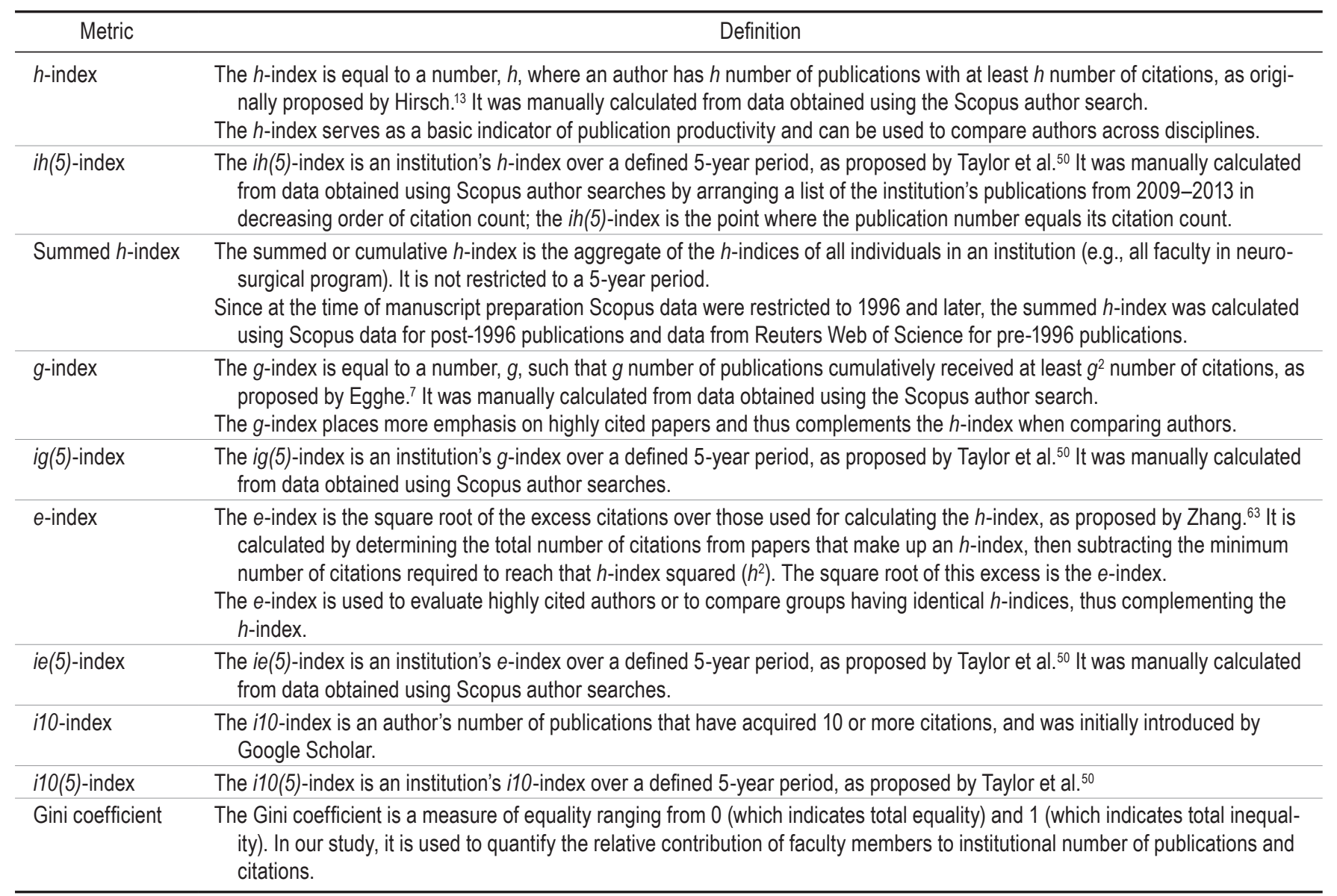

inequality (Table 5). This finding indicates that a few individuals contributed disproportionately to the number of publications and citations. This trend is illustrated in Fig. 1 , which shows the number of publications and citations on a per faculty member basis, grouped by the number of citations received from 2009 to 2013.

One of the most important purposes for conducting this study was to ascertain and provide a verifiable assessment of where our academic productivity stands in relation to other neurosurgical programs. We took advantage of the appraisal of the training programs in the United States as published in the accompanying article in this issue ${ }^{50}$ and tailored our analysis methods, metrics, and period of evaluation to closely match so as to allow for meaningful comparisons.

The performance metrics of the neurosurgery program

TABLE 2. University of Toronto Neurosurgery Program yearly bibliometric indices, 2009-2013

\begin{tabular}{lccccccc}
\hline \multicolumn{1}{c}{ Characteristic } & 2009 & 2010 & 2011 & 2012 & 2013 & Total & Yearly Average \\
\hline Total faculty & 28 & 29 & 28 & 30 & 31 & 146 & 29.2 \\
\hline Total publications & 185 & 256 & 232 & 255 & 289 & 1217 & 243.4 \\
\hline Total citations & 146 & 979 & 2291 & 4147 & 5871 & 13,434 & 2686.8 \\
\hline & & & & & & 5 -Year Average \\
\hline Average papers/faculty & 6.6 & 8.8 & 8.3 & 8.5 & 9.3 & 8.3 \\
\hline Average citations/faculty & 5.2 & 33.8 & 81.8 & 138.2 & 189.4 & 89.68 \\
\hline ih-index & & & & & & 5 -Year Measure \\
\hline ig-index & 4 & 13 & 22 & 29 & 32 & $i h(5)$ & 50 \\
\hline ie-index & 8 & 20 & 30 & 41 & 45 & $i g(5)$ & 80 \\
\hline i10-index & 6.24 & 12.49 & 17.29 & 24.3 & 27.66 & $i e(5)$ & 54.77 \\
\hline
\end{tabular}




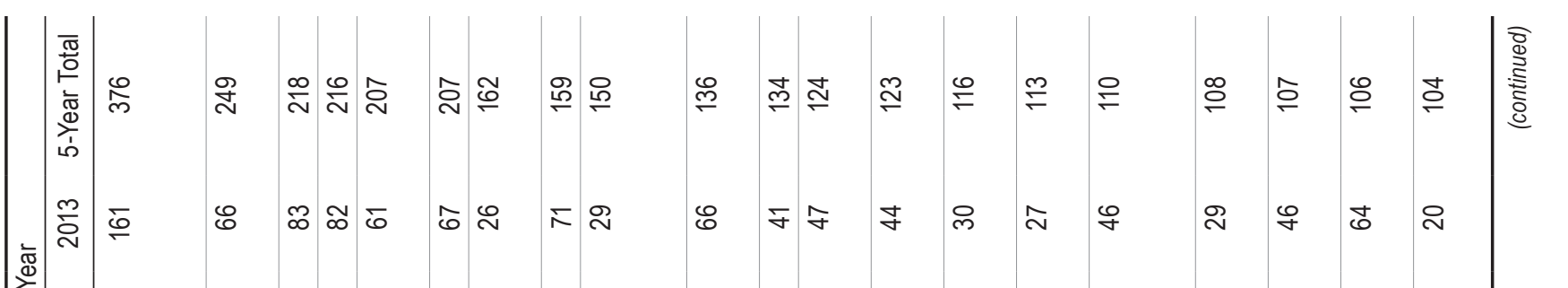

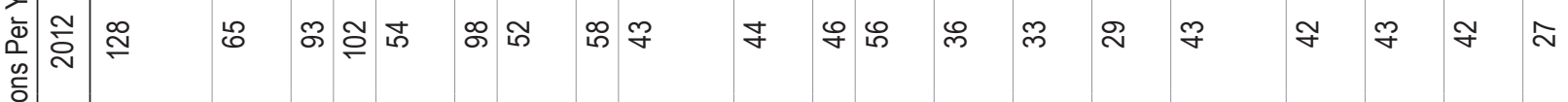

㱒晾

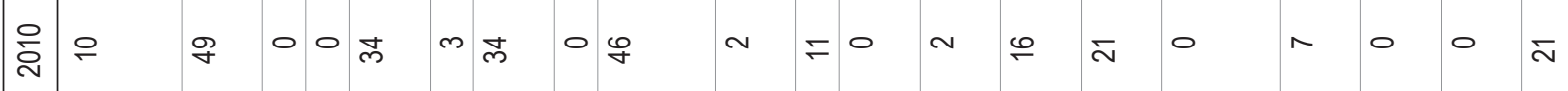

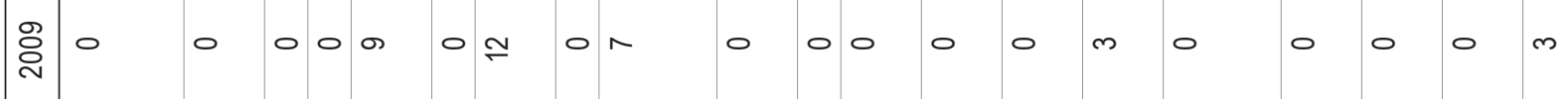

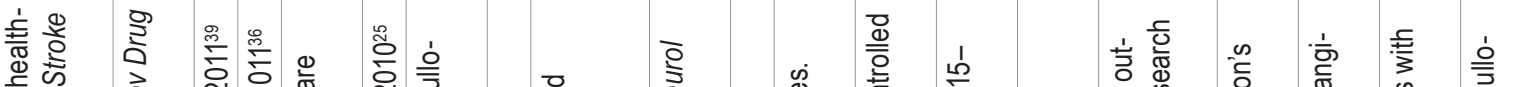

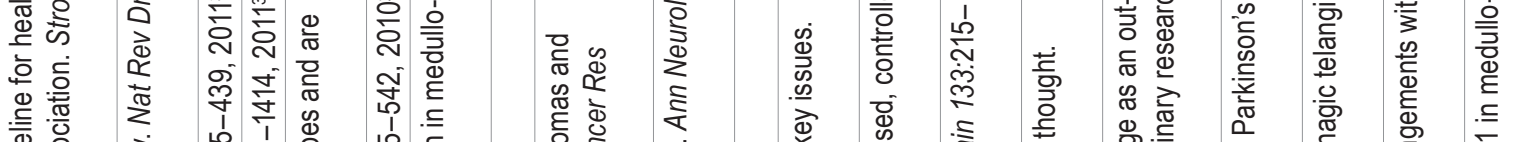

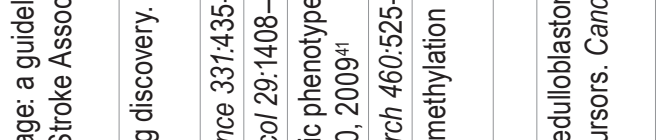

$\stackrel{*}{\stackrel{*}{*}}$

|

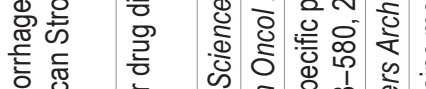

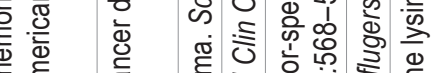

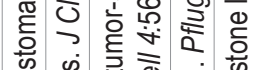

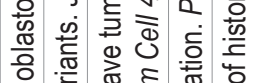

党 亭

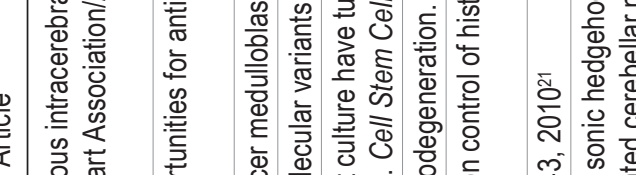

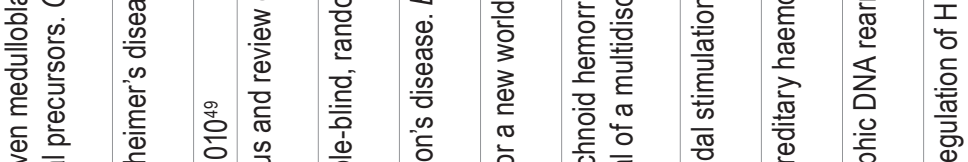

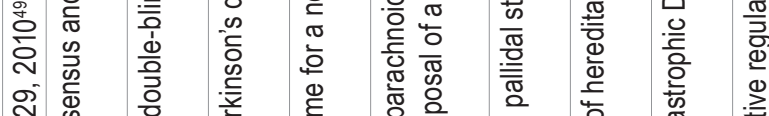

จุ

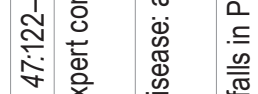

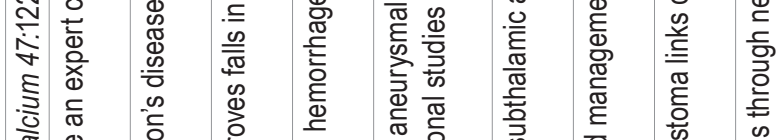

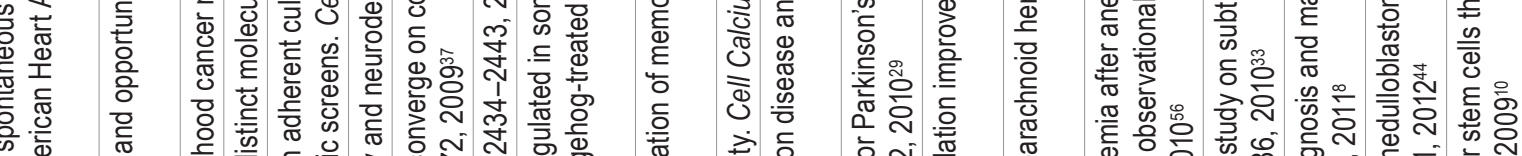

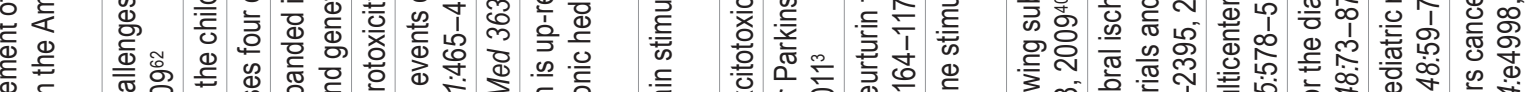

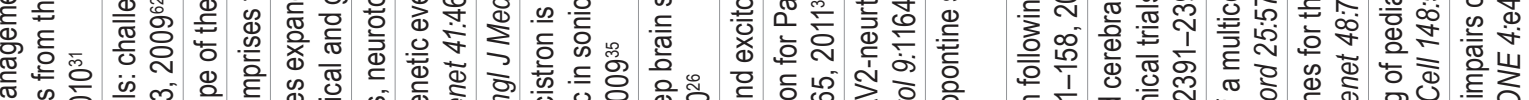

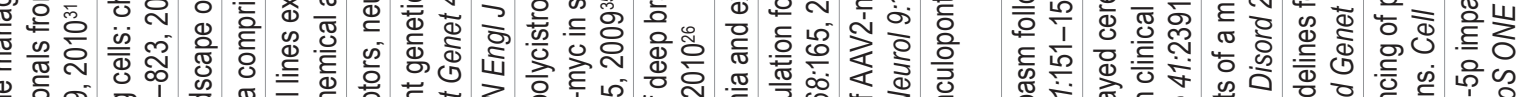

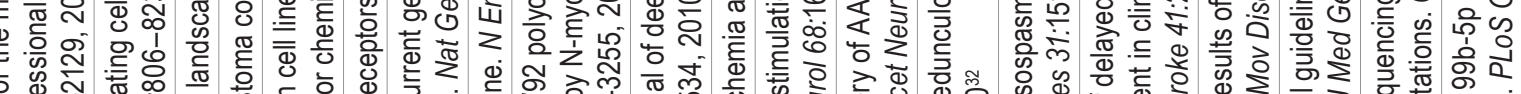

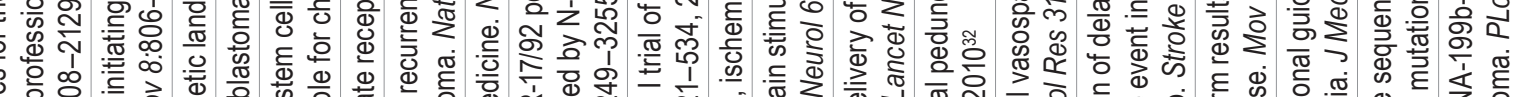

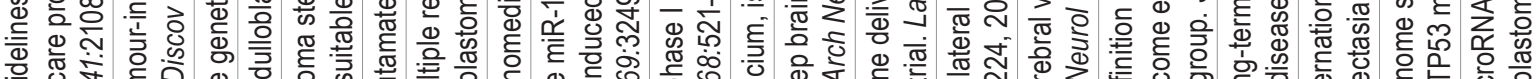

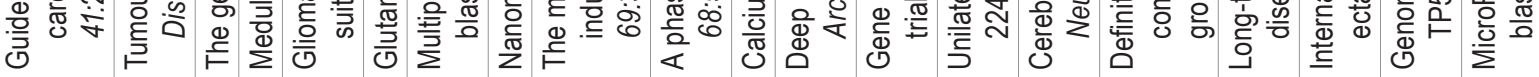

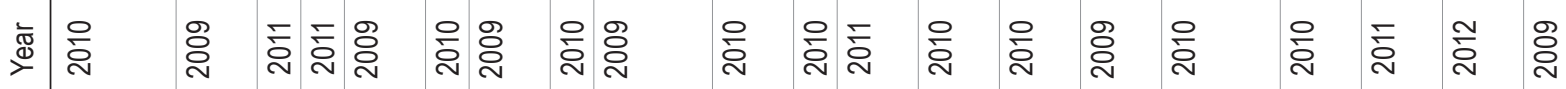

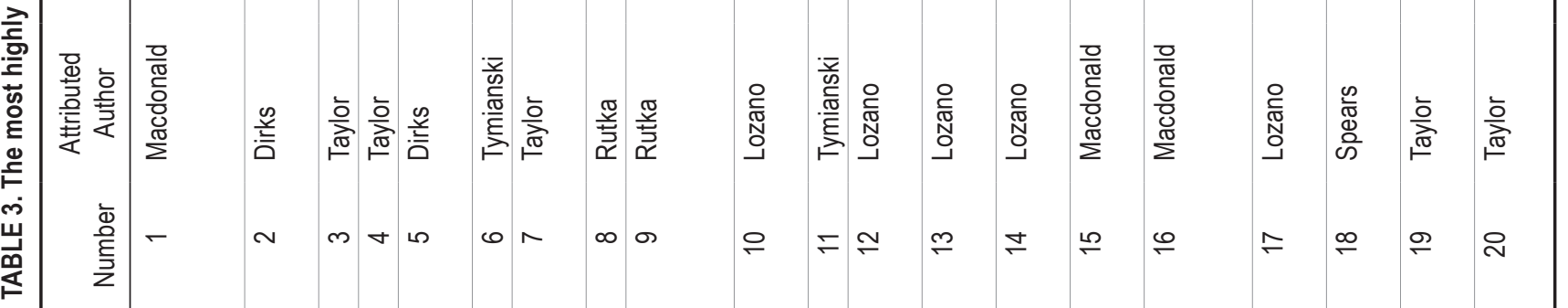




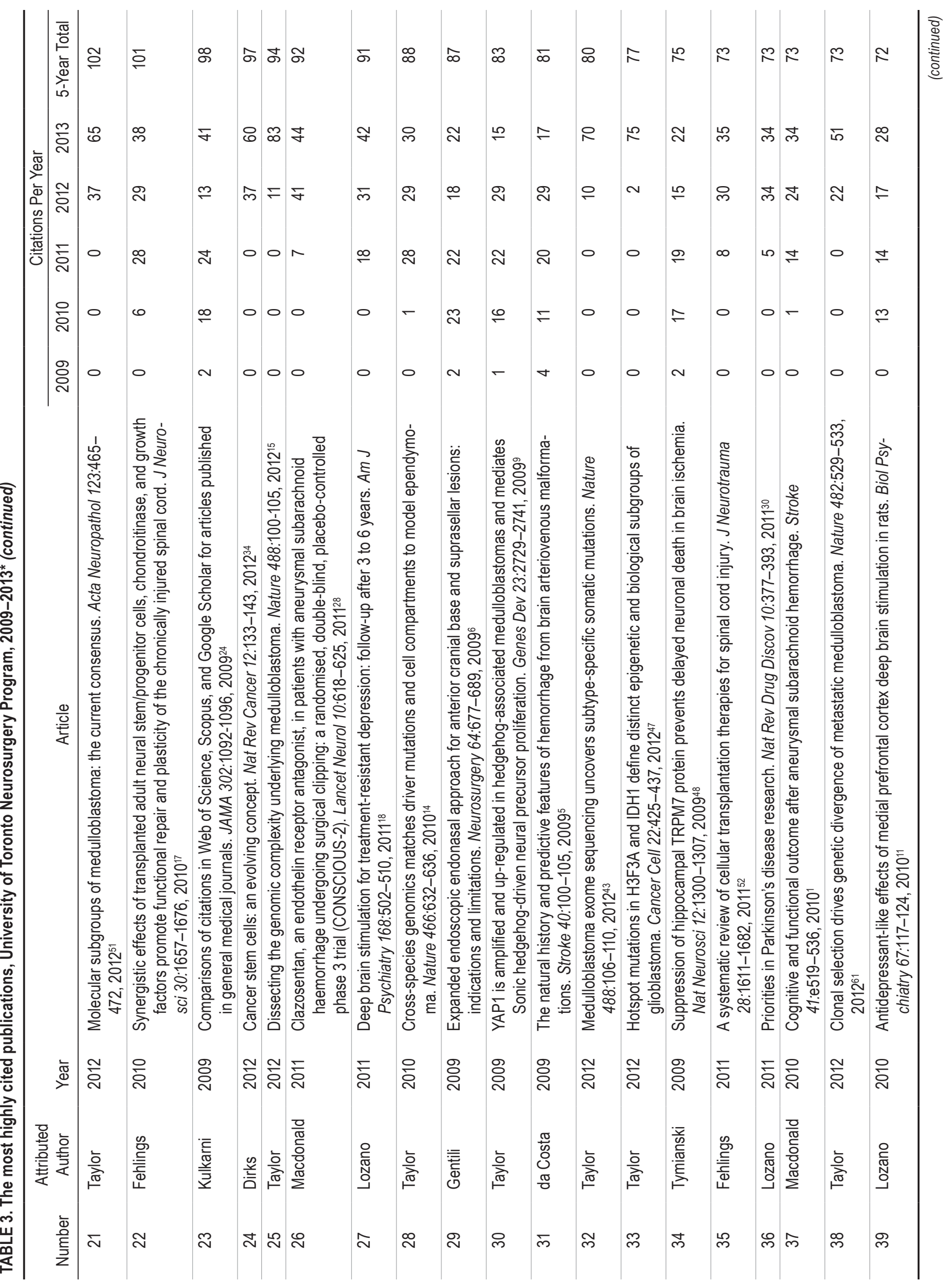




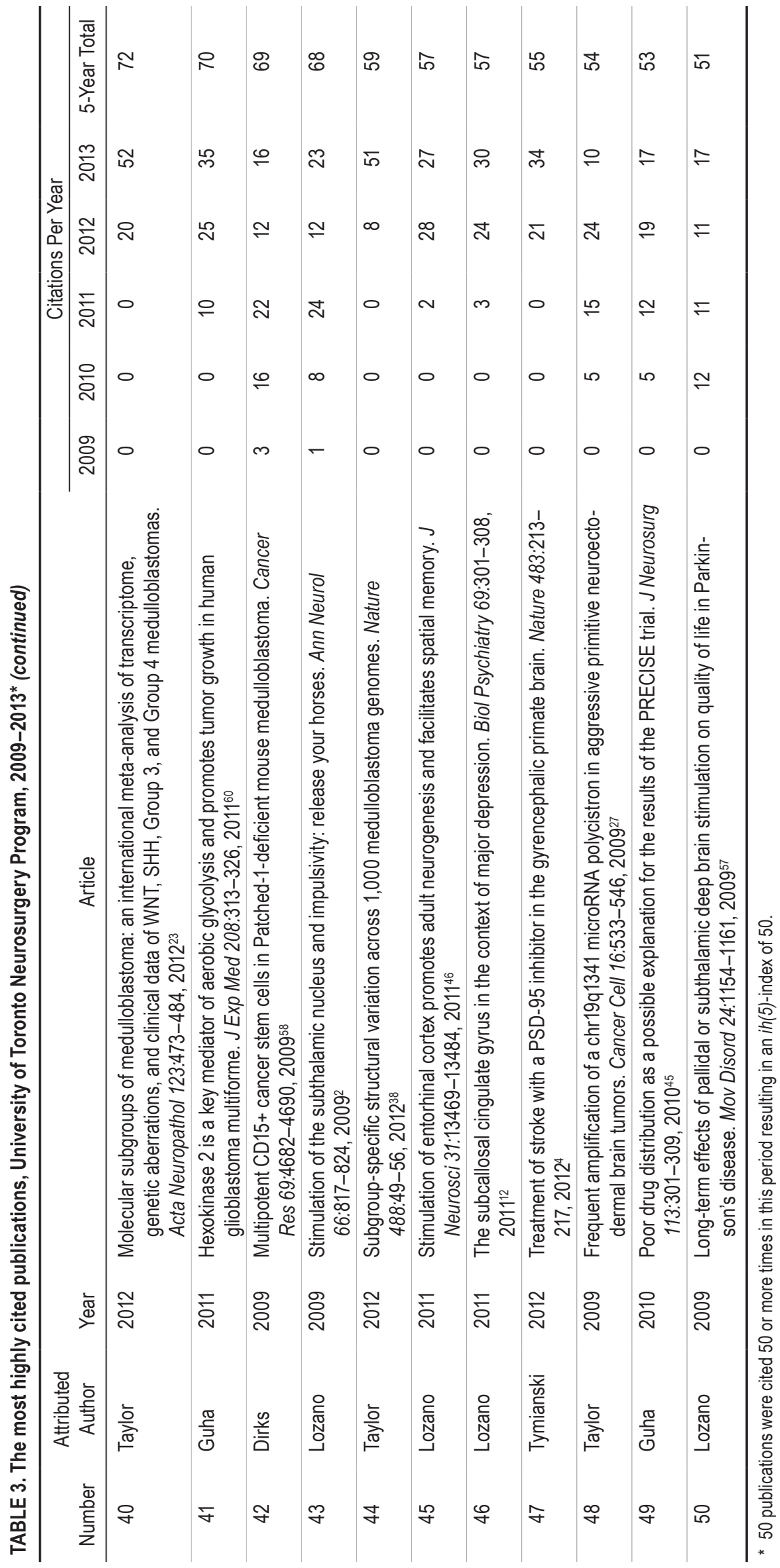


TABLE 4. Comparison of neurosurgery department rankings based upon institutional and summed $h$-index, total publications, and total citations*

\begin{tabular}{|c|c|c|c|c|c|c|c|c|c|}
\hline \multirow[b]{2}{*}{ Institution } & \multicolumn{2}{|c|}{ ih(5)-Index } & \multicolumn{2}{|c|}{ Summed $h$-Index } & \multicolumn{2}{|c|}{ Total Publications } & \multicolumn{2}{|c|}{ Total Citations } & \multirow{2}{*}{$\begin{array}{l}\text { Faculty } \\
\text { Number }\end{array}$} \\
\hline & Rank & Number & Rank & Number & Rank & Number & Rank & Number & \\
\hline University of Toronto & 1 & 50 & 1 & 1117 & 1 & 1217 & 1 & 13,434 & 29.2 \\
\hline University of California, San Francisco & 2 & 42 & 2 & 625 & 2 & 680 & 2 & 9048 & 33 \\
\hline University of California, Los Angeles & 3 & 36 & 6 & 467 & 6 & 360 & 3 & 6038 & 23 \\
\hline University of Pittsburgh & 4 & 31 & 5 & 471 & 4 & 388 & 6 & 4065 & 34 \\
\hline Brigham \& Women's Hospital & 4 & 31 & 17 & 289 & 11 & 263 & 5 & 4250 & 16 \\
\hline Johns Hopkins University & 6 & 29 & 4 & 509 & 3 & 557 & 4 & 4795 & 31 \\
\hline University of Virginia & 7 & 28 & 9 & 361 & 7 & 328 & 8 & 3552 & 14 \\
\hline Duke University Hospital & 8 & 27 & 14 & 298 & 11 & 263 & 7 & 3783 & 15 \\
\hline Ohio State University & 8 & 27 & 23 & 258 & 13 & 261 & 12 & 3013 & 22 \\
\hline $\begin{array}{l}\text { St. Joseph's Hospital/Barrow Neurological } \\
\text { Institute }\end{array}$ & 10 & 26 & 3 & 513 & 5 & 365 & 9 & 3547 & 29 \\
\hline Stanford University & 10 & 26 & 10 & 342 & 9 & 279 & 10 & 3534 & 26 \\
\hline
\end{tabular}

* Data from centers other than Toronto were compiled from Table 3 in Taylor et al. ${ }^{50}$

at the University of Toronto in relation to the top 10 programs with respect to publications is shown in Tables 4 and 5 (data from centers other than Toronto are compiled from Taylor et al. ${ }^{50}$ more specifically, Table 3 and Appendix 1 in that publication). As shown in Table 4, compared with other neurosurgical programs in North America, for the period of the last 5 years, the program in Toronto ranks first for total publications, total citations and $i h(5)$-index. The 1217 publications over the 5-year period are almost double those of the next closest ranking program, the University of California, San Francisco (UCSF). This was not related to having a larger program since the University of Toronto has 29 faculty compared with 33 at UCSF. With 13,434 citations, the University of Toronto also led in total number of citations for papers published in the last 5 years. On the other hand, the mean number of citations per paper over the last 5 years was higher at UCSF 13.3 versus 11.0 in Toronto. In removing the emphasis on the last 5 years and assessing career-long contributions as reflected by the summed $h$-index, current faculty at the University of Toronto had the highest summed $h$-index among programs in North America.

\section{Discussion/Conclusions}

The University of Toronto Neurosurgery Program generates a high number of publications that receive a large number of citations. When compared with the output of other neurosurgery programs in the United States, ${ }^{50}$ the University of Toronto ranks first in papers, in number of citations or in $i h(5)$, that is the institutional $h$-index over the last 5 years.

Given the absence of intimate knowledge concerning the make-up of foreign neurosurgical programs and the technical challenges and limitations that exist, we have not made a comprehensive and validated appraisal of world-

TABLE 5. Comparison of neurosurgery department rankings based upon remaining bibliometric indices*

\begin{tabular}{|c|c|c|c|c|c|c|c|c|}
\hline \multirow[b]{2}{*}{ Institution } & \multicolumn{2}{|c|}{$i g(5)-$ Index } & \multicolumn{2}{|c|}{$i e(5)-$ Index } & \multicolumn{2}{|c|}{ i10(5)-Index } & \multirow{2}{*}{$\begin{array}{l}\text { Publication Gini } \\
\text { Coefficient }\end{array}$} & \multirow{2}{*}{$\begin{array}{l}\text { Citation Gin } \\
\text { Coefficient }\end{array}$} \\
\hline & Rank & Number & Rank & Number & Rank & Number & & \\
\hline University of Toronto & 1 & 80 & 1 & 55 & 1 & 336 & 0.61 & 0.72 \\
\hline University of California, San Francisco & 3 & 66 & 3 & 43 & 2 & 243 & 0.52 & 0.62 \\
\hline University of California, Los Angeles & 2 & 69 & 2 & 52 & 6 & 104 & 0.57 & 0.74 \\
\hline University of Pittsburgh & 11 & 48 & 14 & 31 & 4 & 119 & 0.66 & 0.74 \\
\hline Brigham \& Women's Hospital & 4 & 58 & 3 & 43 & 9 & 84 & 0.50 & 0.59 \\
\hline Johns Hopkins University & 6 & 50 & 11 & 34 & 3 & 135 & 0.48 & 0.60 \\
\hline University of Virginia & 14 & 44 & 17 & 28 & 5 & 107 & 0.53 & 0.42 \\
\hline Duke University Hospital & 5 & 54 & 5 & 41 & 10 & 83 & 0.41 & 0.70 \\
\hline Ohio State University & 13 & 46 & 13 & 32 & 11 & 76 & 0.65 & 0.74 \\
\hline $\begin{array}{l}\text { St. Joseph's Hospital and Medical Center/ } \\
\text { Barrow Neurological Institute }\end{array}$ & 9 & 49 & 8 & 37 & 11 & 76 & 0.61 & 0.65 \\
\hline Stanford University & 9 & 49 & 9 & 36 & 8 & 86 & 0.61 & 0.74 \\
\hline
\end{tabular}

\footnotetext{
* Data from centers other than Toronto were compiled from Appendix Table 1 in Taylor et al..$^{50}$
} 


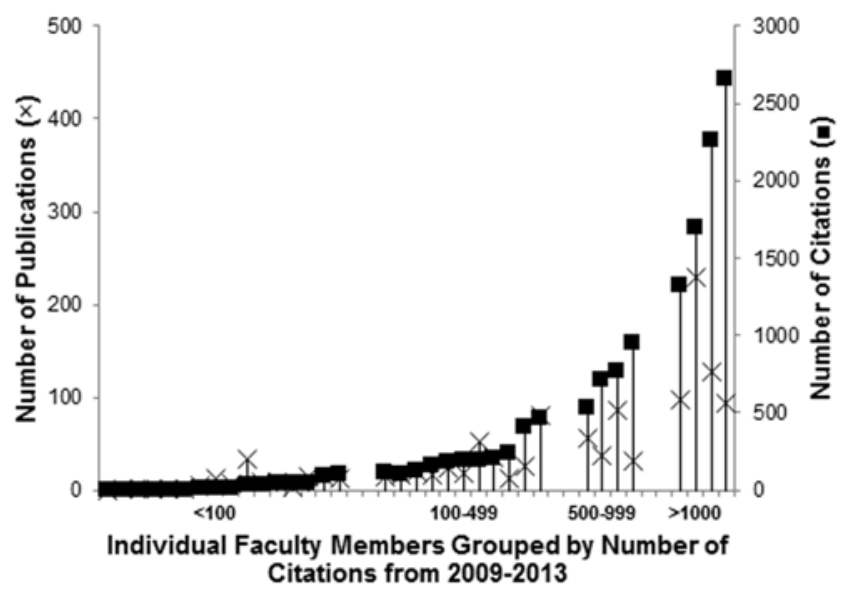

FIG. 1. University of Toronto Neurosurgery Program publications and citations by faculty member. The total number of publications and total number of citations for each individual Toronto neurosurgery faculty member in the 2009-2013 period were plotted in increasing order of citations. Faculty members were grouped according to number of citations in the 5-year period as follows: 1) < 100 citations; 2) 100-499 citations; 3) 500-999 citations; and 4) > 1000 citations.

wide programs. To derive an estimate of world rankings, we arbitrarily surveyed the top 20 ranked universities in the world according to the Times Higher Education 20132014 World University Rankings ${ }^{53}$ and assumed that the top universities may be home to the highest academically productive neurosurgery programs. Such an analysis revealed that 5 of the 20 top ranked universities, including the University of Toronto, are outside the US. The other 4 top ranked universities have a relatively small neurosurgical faculty according to their websites (Cambridge University, $\mathrm{n}=7$; Imperial College London, $\mathrm{n}=8$; Oxford University, $n=14$; Swiss Federal Institute of Technology Zurich, $\mathrm{n}=0$ ). Largely for this reason, an analysis of their publication and citation numbers does not place them at the top of the neurosurgery rankings. A recently appearing article in this journal ranking the productivity of neurosurgeons in Great Britain and Ireland also supports this assertion. ${ }^{59}$ With the body of data we have in hand, it is therefore likely that the neurosurgery program at the University of Toronto ranks first in the world in academic output as measured here.

A limitation of our work is that publications and citations are but isolated measures of academic productivity and impact. As the old adage goes, "Not everything that matters can be measured and not everything that can be measured matters." Several other factors that may be important drivers of impact are not captured by this analysis. Nevertheless, using the number and citation data for manuscripts validated for our program provides a practical, operational and easily quantifiable measure of academic output which can be readily ascertained and benchmarked. We have not emphasized the techniques used in our measures nor their attributes and limitations as they are well covered in the recent work analyzing academic productivity in North American neurosurgical programs in an accompanying article. ${ }^{50}$

We cannot be certain of what factors were the most important drivers of academic productivity. Reaching this high level of academic activity in the Toronto program is multifactorial and includes setting the course of our program and assembling the residents and faculty that can execute. Among the factors that may contribute are: 1) a longstanding interest and tradition of advancing the field of neurosurgery; 2) a mission to be academic leaders; 3) a policy of selecting residents who have a strong interest in research; 4) the allocation of the time in research and financial support of our residents and their encouragement to obtain a graduate degree in the context of our surgeonscientist program; and 5) an emphasis on the recruitment of neurosurgeon-scientists to our faculty.

There are also "softer" factors which may have contributed. For example we function in a largely single-payer, predictable reimbursement environment and have stable funding for our clinical activities. A likely important factor also resides in the centralization of academic activity in Toronto. While Toronto is ranked as the fourth largest city by population in North America behind Mexico City, New York, and Los Angeles, we have a single medical school and a single neurosurgery program. This avoids duplication; reduces dilution of programs for complex, rare, or uncommon conditions; drives high-volume subspecialization and enables critical mass in various areas of neurosurgery; and facilitates patient recruitment for clinical trials and reduces internal competition for caseload.

The consequences of this high-level academic activity are difficult to quantify. We can speculate that they may include attracting and retaining residents and faculty, securing preferred academic and industrial partnerships, securing grants and awards, and driving philanthropy. In discussions with our residents, it is clear that academic opportunities in the residency program figure prominently in their choice of residency program. Here, the ability to access research opportunities, the training in a program with a strong research tone and environment, and the feeling that exposure and opportunities in research will make them attractive in an increasingly competitive job market are factors which influence their selection of where to train.

The ultimate goal of research in our specialty is to solve the important problems that our patients face across all fields of neurosurgery. Each subspecialty in neurosurgery has formidable and intractable challenges: malignant tumors, spinal cord injury, subarachnoid hemorrhage, head injury, and so on. Who better to take on these problems and discover treatments which change the way we practice and improve the lives of our patients than neurosurgeons? Albeit not the sole source, academic programs are the prime repository of innovation in neurosurgery. We encourage the programs to use this information as a benchmark to track their performance and evolution. As the old adage goes, if it is worth doing it is worth measuring.

\section{References}

1. Al-Khindi T, Macdonald RL, Schweizer TA: Cognitive and functional outcome after aneurysmal subarachnoid hemorrhage. Stroke 41:e519-e536, 2010

2. Ballanger B, van Eimeren T, Moro E, Lozano AM, Hamani C, Boulinguez P, et al: Stimulation of the subthalamic 
nucleus and impulsivity: release your horses. Ann Neurol 66:817-824, 2009

3. Bronstein JM, Tagliati M, Alterman RL, Lozano AM, Volkmann J, Stefani A, et al: Deep brain stimulation for Parkinson disease: an expert consensus and review of key issues. Arch Neurol 68:165, 2011

4. Cook DJ, Teves L, Tymianski M: Treatment of stroke with a PSD-95 inhibitor in the gyrencephalic primate brain. Nature 483:213-217, 2012

5. da Costa L, Wallace MC, terBrugge KG, O'Kelly C, Willinsky RA, Tymianski M: The natural history and predictive features of hemorrhage from brain arteriovenous malformations. Stroke 40:100-105, 2009

6. Dehdashti AR, Ganna A, Witterick I, Gentili F: Expanded endoscopic endonasal approach for anterior cranial base and suprasellar lesions: indications and limitations. Neurosurgery 64:677-689, 2009

7. Egghe L: Theory and practise of the g-index. Scientometrics 69:131-152, 2006

8. Faughnan ME, Palda VA, Garcia-Tsao G, Geisthoff UW, McDonald J, Proctor DD, et al: International guidelines for the diagnosis and management of hereditary haemorrhagic telangiectasia. J Med Genet 48:73-87, 2011

9. Fernandez-L A, Northcott PA, Dalton J, Fraga C, Ellison $\mathrm{D}$, Angers S, et al: YAP1 is amplified and up-regulated in hedgehog-associated medulloblastomas and mediates Sonic hedgehog-driven neural precursor proliferation. Genes Dev 23:2729-2741, 2009

10. Garzia L, Andolfo I, Cusanelli E, Marino N, Petrosino G, De Martino D, et al: MicroRNA-199b-5p impairs cancer stem cells through negative regulation of HES1 in medulloblastoma. PLoS ONE 4:e4998, 2009

11. Hamani C, Diwan M, Macedo CE, Brandão ML, Shumake J, Gonzalez-Lima F, et al: Antidepressant-like effects of medial prefrontal cortex deep brain stimulation in rats. Biol Psychiatry 67:117-124, 2010

12. Hamani C, Mayberg H, Stone S, Laxton A, Haber S, Lozano AM: The subcallosal cingulate gyrus in the context of major depression. Biol Psychiatry 69:301-308, 2011

13. Hirsch JE: An index to quantify an individual's scientific research output. Proc Natl Acad Sci U S A 102:16569-16572, 2005

14. Johnson RA, Wright KD, Poppleton H, Mohankumar KM, Finkelstein D, Pounds SB, et al: Cross-species genomics matches driver mutations and cell compartments to model ependymoma. Nature 466:632-636, 2010

15. Jones DT, Jäger N, Kool M, Zichner T, Hutter B, Sultan M, et al: Dissecting the genomic complexity underlying medulloblastoma. Nature 488:100-105, 2012

16. Kalra RR, Kestle JR: An assessment of academic productivity in pediatric neurosurgery. J Neurosurg Pediatr 12:262265,2013

17. Karimi-Abdolrezaee S, Eftekharpour E, Wang J, Schut D, Fehlings MG: Synergistic effects of transplanted adult neural stem/progenitor cells, chondroitinase, and growth factors promote functional repair and plasticity of the chronically injured spinal cord. J Neurosci 30:1657-1676, 2010

18. Kennedy SH, Giacobbe P, Rizvi SJ, Placenza FM, Nishikawa Y, Mayberg HS, et al: Deep brain stimulation for treatmentresistant depression: follow-up after 3 to 6 years. Am J Psychiatry 168:502-510, 2011

19. Khan N, Thompson CJ, Choudhri AF, Boop FA, Klimo P Jr: Part I: The application of the h-index to groups of individuals and departments in academic neurosurgery. World Neurosurg 80:759-765, 765.e1-765.e3, 2013

20. Khan NR, Thompson CJ, Taylor DR, Venable GT, Wham RM, Michael LM II, et al: An analysis of publication productivity for 1225 academic neurosurgeons and 99 departments in the United States. J Neurosurg 120:746-755, 2014
21. Kim BY, Rutka JT, Chan WC: Nanomedicine. N Engl J Med 363:2434-2443, 2010

22. Klimo P Jr, Venable GT, Khan NR, Taylor DR, Shepherd BA, Thompson CJ, et al: Bibliometric evaluation of pediatric neurosurgery in North America. J Neurosurg Pediatr 14:695-703, 2014

23. Kool M, Korshunov A, Remke M, Jones DT, Schlanstein M, Northcott PA, et al: Molecular subgroups of medulloblastoma: an international meta-analysis of transcriptome, genetic aberrations, and clinical data of WNT, SHH, Group 3, and Group 4 medulloblastomas. Acta Neuropathol 123:473-484, 2012

24. Kulkarni AV, Aziz B, Shams I, Busse JW: Comparisons of citations in Web of Science, Scopus, and Google Scholar for articles published in general medical journals. JAMA 302:1092-1096, 2009

25. Lau A, Tymianski M: Glutamate receptors, neurotoxicity and neurodegeneration. Pflugers Arch 460:525-542, 2010

26. Laxton AW, Tang-Wai DF, McAndrews MP, Zumsteg D, Wennberg R, Keren R, et al: A phase I trial of deep brain stimulation of memory circuits in Alzheimer's disease. Ann Neurol 68:521-534, 2010

27. Li M, Lee KF, Lu Y, Clarke I, Shih D, Eberhart C, et al: Frequent amplification of a chr19q13.41 microRNA polycistron in aggressive primitive neuroectodermal brain tumors. Cancer Cell 16:533-546, 2009

28. Macdonald RL, Higashida RT, Keller E, Mayer SA, Molyneux A, Raabe A, et al: Clazosentan, an endothelin receptor antagonist, in patients with aneurysmal subarachnoid haemorrhage undergoing surgical clipping: a randomised, doubleblind, placebo-controlled phase 3 trial (CONSCIOUS-2). Lancet Neurol 10:618-625, 2011

29. Marks WJ Jr, Bartus RT, Siffert J, Davis CS, Lozano A, Boulis N, et al: Gene delivery of AAV2-neurturin for Parkinson's disease: a double-blind, randomised, controlled trial. Lancet Neurol 9:1164-1172, 2010

30. Meissner WG, Frasier M, Gasser T, Goetz CG, Lozano A, Piccini P, et al: Priorities in Parkinson's disease research. Nat Rev Drug Discov 10:377-393, 2011

31. Morgenstern LB, Hemphill JC III, Anderson C, Becker K, Broderick JP, Connolly ES Jr, et al: Guidelines for the management of spontaneous intracerebral hemorrhage: a guideline for healthcare professionals from the American Heart Association/American Stroke Association. Stroke 41:21082129,2010

32. Moro E, Hamani C, Poon YY, Al-Khairallah T, Dostrovsky JO, Hutchison WD, et al: Unilateral pedunculopontine stimulation improves falls in Parkinson's disease. Brain 133:215224,2010

33. Moro E, Lozano AM, Pollak P, Agid Y, Rehncrona S, Volkmann J, et al: Long-term results of a multicenter study on subthalamic and pallidal stimulation in Parkinson's disease. Mov Disord 25:578-586, 2010

34. Nguyen LV, Vanner R, Dirks P, Eaves CJ: Cancer stem cells: an evolving concept. Nat Rev Cancer 12:133-143, 2012

35. Northcott PA, Fernandez-L A, Hagan JP, Ellison DW, Grajkowska W, Gillespie Y, et al: The miR-17/92 polycistron is up-regulated in sonic hedgehog-driven medulloblastomas and induced by $\mathrm{N}$-myc in sonic hedgehog-treated cerebellar neural precursors. Cancer Res 69:3249-3255, 2009

36. Northcott PA, Korshunov A, Witt H, Hielscher T, Eberhart CG, Mack S, et al: Medulloblastoma comprises four distinct molecular variants. J Clin Oncol 29:1408-1414, 2011

37. Northcott PA, Nakahara Y, Wu X, Feuk L, Ellison DW, Croul $S$, et al: Multiple recurrent genetic events converge on control of histone lysine methylation in medulloblastoma. Nat Genet 41:465-472, 2009

38. Northcott PA, Shih DJ, Peacock J, Garzia L, Morrissy AS, Zichner T, et al: Subgroup-specific structural variation across 1,000 medulloblastoma genomes. Nature 488:49-56, 2012 
39. Parsons DW, Li M, Zhang X, Jones S, Leary RJ, Lin JC, et al: The genetic landscape of the childhood cancer medulloblastoma. Science 331:435-439, 2011

40. Pluta RM, Hansen-Schwartz J, Dreier J, Vajkoczy P, Macdonald RL, Nishizawa S, et al: Cerebral vasospasm following subarachnoid hemorrhage: time for a new world of thought. Neurol Res 31:151-158, 2009

41. Pollard SM, Yoshikawa K, Clarke ID, Danovi D, Stricker S, Russell R, et al: Glioma stem cell lines expanded in adherent culture have tumor-specific phenotypes and are suitable for chemical and genetic screens. Cell Stem Cell 4:568-580, 2009

42. Ponce FA, Lozano AM: Academic impact and rankings of American and Canadian neurosurgical departments as assessed using the h index. J Neurosurg 113:447-457, 2010

43. Pugh TJ, Weeraratne SD, Archer TC, Pomeranz Krummel DA, Auclair D, Bochicchio J, et al: Medulloblastoma exome sequencing uncovers subtype-specific somatic mutations. Nature 488:106-110, 2012

44. Rausch T, Jones DT, Zapatka M, Stütz AM, Zichner T, Weischenfeldt J, et al: Genome sequencing of pediatric medulloblastoma links catastrophic DNA rearrangements with TP53 mutations. Cell 148:59-71, 2012

45. Sampson JH, Archer G, Pedain C, Wembacher-Schröder E, Westphal M, Kunwar S, et al: Poor drug distribution as a possible explanation for the results of the PRECISE trial. J Neurosurg 113:301-309, 2010

46. Stone SS, Teixeira CM, Devito LM, Zaslavsky K, Josselyn SA, Lozano AM, et al: Stimulation of entorhinal cortex promotes adult neurogenesis and facilitates spatial memory. J Neurosci 31:13469-13484, 2011

47. Sturm D, Witt H, Hovestadt V, Khuong-Quang DA, Jones DT, Konermann C, et al: Hotspot mutations in H3F3A and IDH1 define distinct epigenetic and biological subgroups of glioblastoma. Cancer Cell 22:425-437, 2012

48. Sun HS, Jackson MF, Martin LJ, Jansen K, Teves L, Cui H, et al: Suppression of hippocampal TRPM7 protein prevents delayed neuronal death in brain ischemia. Nat Neurosci 12:1300-1307, 2009

49. Szydlowska K, Tymianski M: Calcium, ischemia and excitotoxicity. Cell Calcium 47:122-129, 2010

50. Taylor DR, Venable GT, Jones GM, Lepard JR, Roberts ML, Saleh N, et al: Five-year institutional bibliometric profiles for 103 US neurosurgical residency programs. J Neurosurg [epub ahead of print June 26, 2015. DOI: 10.3171/2014.10. JNS141025]

51. Taylor MD, Northcott PA, Korshunov A, Remke M, Cho YJ, Clifford SC, et al: Molecular subgroups of medulloblastoma: the current consensus. Acta Neuropathol 123:465-472, 2012

52. Tetzlaff W, Okon EB, Karimi-Abdolrezaee S, Hill CE, Sparling JS, Plemel JR, et al: A systematic review of cellular transplantation therapies for spinal cord injury. J Neurotrauma 28:1611-1682, 2011

53. Times Higher Education: World University Rankings 2013-2014. (http://www.timeshighereducation.co.uk/worlduniversity-rankings/2013-14/world-ranking)[Accessed May 21, 2015]

54. Tomei KL, Nahass MM, Husain Q, Agarwal N, Patel SK, Svider PF, et al: A gender-based comparison of academic rank and scholarly productivity in academic neurological surgery. J Clin Neurosci 21:1102-1105, 2014
55. Venable GT, Khan NR, Taylor DR, Thompson CJ, Michael LM, Klimo P Jr: A correlation between National Institutes of Health funding and bibliometrics in neurosurgery. World Neurosurg 81:468-472, 2014

56. Vergouwen MD, Vermeulen M, van Gijn J, Rinkel GJ, Wijdicks EF, Muizelaar JP, et al: Definition of delayed cerebral ischemia after aneurysmal subarachnoid hemorrhage as an outcome event in clinical trials and observational studies: proposal of a multidisciplinary research group. Stroke 41:2391-2395, 2010

57. Volkmann J, Albanese A, Kulisevsky J, Tornqvist AL, Houeto JL, Pidoux B, et al: Long-term effects of pallidal or subthalamic deep brain stimulation on quality of life in Parkinson's disease. Mov Disord 24:1154-1161, 2009

58. Ward RJ, Lee L, Graham K, Satkunendran T, Yoshikawa $\mathrm{K}$, Ling E, et al: Multipotent CD15+ cancer stem cells in patched-1-deficient mouse medulloblastoma. Cancer Res 69:4682-4690, 2009

59. Wilkes FA, Akram H, Hyam JA, Kitchen ND, Hariz MI, Zrinzo L: Publication productivity of neurosurgeons in Great Britain and Ireland. J Neurosurg 122:948-954, 2015

60. Wolf A, Agnihotri S, Micallef J, Mukherjee J, Sabha N, Cairns R, et al: Hexokinase 2 is a key mediator of aerobic glycolysis and promotes tumor growth in human glioblastoma multiforme. J Exp Med 208:313-326, 2011

61. Wu X, Northcott PA, Dubuc A, Dupuy AJ, Shih DJ, Witt H, et al: Clonal selection drives genetic divergence of metastatic medulloblastoma. Nature 482:529-533, 2012

62. Zhou BB, Zhang H, Damelin M, Geles KG, Grindley JC, Dirks PB: Tumour-initiating cells: challenges and opportunities for anticancer drug discovery. Nat Rev Drug Discov 8:806-823, 2009

63. Zhang CT: The e-index, complementing the h-index for excess citations. PLoS ONE 4:e5429, 2009

\section{Author Contributions}

Conception and design: AM Lozano, CS Lozano. Acquisition of data: AM Lozano, CS Lozano. Analysis and interpretation of data: AM Lozano, CS Lozano, Tam. Drafting the article: AM Lozano, CS Lozano. Critically revising the article: all authors. Reviewed submitted version of manuscript: all authors. Approved the final version of the manuscript on behalf of all authors: AM Lozano. Statistical analysis: AM Lozano, CS Lozano, Tam. Administrative/technical/material support: Tam. Study supervision: AM Lozano.

\section{Supplemental Information Companion Paper}

Taylor DR, Venable GT, Jones GM, Lepard JR, Roberts ML, Saleh N, et al: Five-year institutional bibliometric profiles for 103 US neurosurgical residency programs. DOI: 10.3171/2014.10. JNS141025.

\section{Correspondence}

Andres M. Lozano, Division of Neurosurgery, University of Toronto, Toronto Western Hospital, 399 Bathurst St., West Wing 4-431, Toronto, ON M5T 2S8, Canada. email: lozano@ uhnresearch.ca. 